\title{
Serum levels of soluble Fas, soluble tumor necrosis factor-receptor II, interleukin-2 receptor and interleukin-8 as early predictors of hepatocellular carcinoma in Egyptian patients with hepatitis $C$ virus genotype-4
}

\author{
Abdel-Rahman N Zekri" ${ }^{*}$, Hanaa M Alam El-Din ${ }^{1}$, Abeer A Bahnassy², Naglaa A Zayed ${ }^{3}$, Waleed S Mohamed', \\ Suzan H El-Masry ${ }^{4}$, Sayed K Gouda ${ }^{4}$, Gamal Esmat ${ }^{3}$
}

\begin{abstract}
Background: Liver disease progression from chronic hepatitis $\mathrm{C}$ virus (HCV) infection to hepatocellular carcinoma (HCC) is associated with an imbalance between T-helper 1 and T-helper 2 cytokines. Evaluation of cytokines as possible candidate biomarkers for prediction of HCC was performed using soluble Fas (sFas), soluble tumor necrosis factor receptor-II (sTNFR-II), interleukin-2 receptor (IL-2R) and interleukin-8 (IL-8).

Results: The following patients were recruited: 79 with HCV infection, 30 with HCC, 32 with chronic liver disease associated with elevated liver enzyme levels (with or without cirrhosis) in addition to 17 with chronic HCV with persistent normal alanine aminotransferase levels (PNALT). Nine normal persons negative either for HCV or for hepatitis B virus were included as a control group. All persons were tested for sFas, sTNFR-II, IL-2R and IL-8 in their serum by quantitative ELISA. HCC patients had higher levels of liver enzymes but lower log-HCV titer when compared to the other groups. HCC patients had also significantly higher levels of sFas, sTNFR-II and IL-2R and significantly lower levels of IL-8 when compared to the other groups. Exclusion of HCC among patients having PNALT could be predicted with $90 \%$ sensitivity and $70.6 \%$ specificity when sTNFR-II is $\geq 389 \mathrm{pg} / \mathrm{ml}$ or IL-8 is $<290$ $\mathrm{pg} / \mathrm{ml}$.
\end{abstract}

Conclusions: Serum TNFR-II, IL-2R $\alpha$ and IL-8, may be used as combined markers in HCV-infected cases for patients at high risk of developing HCC; further studies, however, are mandatory to check these findings before their application at the population level.

\section{Background}

Hepatocellular carcinoma (HCC) ranks as the fifth most common cancer around the world and the third most frequent cause of cancer-related death. It represents the most common primary malignant tumor of the liver and is one of the major causes of death among patients with cirrhosis [1]. The increased incidence of HCC in the United States as well as in Japan over the past 20 to 30 years [2,3] has been partially attributed to the emergence of the hepatitis

\footnotetext{
* Correspondence: ncizekri@yahoo.com
'Virology and Immunology Unit, Cancer Biology, National Cancer Institute,

* Correspondence: ncizekri@yahoo.com
'Virology and Immunology Unit, Cancer Biology, National Cancer Institute,
} Cairo University, Cairo, Egypt

$\mathrm{C}$ virus (HCV), an established risk factor for developing $\mathrm{HCC}[4,5]$. The prevalence of $\mathrm{HCV}$ infection varies significantly; higher rates have been reported in African and Asian countries, whereas industrialized nations in North America, northern and western Europe, and Australia had lower prevalence rates [6]. Egypt has the highest prevalence of HCV in the world, ranging from 6 to 28\% [7-10], with an average of approximately $13.8 \%$ in the general population and there is an expected increase in hepatitis C-related mortality in that country [11].

The continued viral replication and persistent attempt by a less than optimal immune response to eliminate 
HCV-infected cells are implicated in hepatocyte aberrations, accumulation of chromosomal damage and possibly initiation of hepatic carcinogenesis [12]. The prognosis of $\mathrm{HCC}$ is generally most serious with a great need for serum markers that could be used for its early detection and, consequently, to start a therapeutical procedure as soon as possible, potentially at a curable phase. Serum $\alpha$-fetoprotein (AFP) levels are frequently not elevated at a significant proportion in patients with early-stage, potentially curable, HCC. Therefore, other markers should have been studied in an attempt to identify a more sensitive laboratory test.

Cytokines are small secreted proteins which regulate immunity, inflammation and haematopoiesis in connection with liver disease progression due to chronic $\mathrm{HCV}$ infection, which is associated with an imbalance between pro- and anti-inflammatory cytokines. Therefore, elevated serum cytokines could be a risk factor for the occurrence of $\mathrm{HCC}$ in patients with $\mathrm{HCV}$ related chronic hepatitis and cirrhosis. Cytokines were shown to be used as biomarkers for early detection of HCC [13] in addition to their possible use as potential predictors for interferon (IFN) treatment in HCV genotype-4 patients [14]. Several cytokines are involved in the process of HCC invasion and metastasis, including soluble Fas (sFas), soluble tumor necrosis factor receptor-II (sTNFR-II), interleukin-2 receptor (IL-2R) and interleukin-8 (IL-8). As the knowledge of tumor biology becomes progressively clear, more and more new biomarkers with high sensitivity and specificity could be found and then routinely used for clinical assays.

The sFas, obviously increased in HCC with a significant difference between patients of chronic liver disease (CLD) and normal controls, was found to correlate with the severity of liver disease and to resist the occurrence of HCC apoptosis $[15,16]$. In chronic hepatitis B virus (HBV) or HCV infected patients, serum IL-2R was used both to screen high-risk patients and to monitor treatment responses in patients with hepatitis who develop HCC. Serum IL-2R appeared not only with a significantly greater frequency than AFP, but was a more sensitive marker of successful treatment and recurrence of HCC as well [17].

Circulating TNF- $\alpha$ level increases during HBV [18-22] and HCV infection [18,23-26] and is correlated with the severity of hepatic inflammation, fibrosis and tissue injury $[18,22,24,27]$. TNF- $\alpha$ plays a role in initiating fibrogenesis through binding to specific cellular receptors; i.e., TNFRs [28], which can be proteolytically cleaved into two soluble forms: sTNFR-I and sTNFR-II. High concentration of sTNFR-II has been observed for prolonged periods in the circulation of patients with various inflammatory diseases (including $\mathrm{HCV}$ infection), making sTNFR-II an ideal serum biomarker for characterizing type 1 immune response [29-32]. Moreover, IL-8 contributes to human cancer progression through potential mitogenic, and angiogenic functions. IL-8 expressions plays a more critical role in the metastatic potential of human HCC (such as vascular invasion) than in angiogenesis or tumor proliferation [33]. Our aim was to evaluate the serum levels of sFas, TNFR-II, IL-2R and IL-8 as possible candidate biomarkers for an early detection of HCC.

\section{Results}

The clinical characteristics of the studied groups are shown in Table 1. All recruited patients were positive for HCV antibodies, PCR for HCV RNA and all had genotype-4. Mean age of patients with HCC was significantly higher than that of the other groups $(p<0.001)$. Liver function tests were significantly elevated, whereas log-HCV titer was significantly lower in HCC patients $(p<0.001)$ when compared to patients with chronic hepatitis $C$ with persistent normal alanine aminotransferase levels (PNALT) and chronic liver disease (CLD) patients. Figure 1 shows the distribution of log-HCV titer in the different study groups, which included 68 men and 29 women. Mann-Whitney test was used for comparing log-HCV, sFas, sTNFR-II, sIL-2R and IL-8 values with gender. Comparing the means of men versus women, the former had only higher and significant ( $p=$ $0.04)$ log-HCV titer $(11.16 \pm 4.1)$ and $(9.7 \pm 1.5)$, respectively; however, all other markers did not statistically differ.

Table 2 depicts the comparison of the serum levels of sFas, sTNFR-II, sIL-2R $\alpha$ and IL-8. HCC patients had higher sFas, sTNFR-II and sIL-2R than patients with PNALT, CLD and normal controls with a significant difference for sFas between HCC patients and control $(p<$ 0.001). The sTNFR-II was significantly elevated in HCC patients compared to those with PNALT and CLD $(p<$ $0.001)$, whereas SIL-2R was significantly elevated in HCC patients when compared to those with PNALT

Table 1 Patients characteristics and log-HCV titer among the different study groups

\begin{tabular}{lccccc}
\hline Variables & $\begin{array}{c}\text { Control } \\
(\mathbf{9})\end{array}$ & $\begin{array}{c}\text { PNALT } \\
\mathbf{( 1 7 )}\end{array}$ & CLD (32) & HCC (30) & p-value \\
\hline M/W & $7 / 2$ & $12 / 5$ & $24 / 8$ & $25 / 5$ & $<0.001$ \\
\hline Age (years): & $50.9 \pm 4.6^{\mathrm{b}}$ & $\begin{array}{c}35.1 \pm \\
11.5^{\mathrm{c}}\end{array}$ & $43.4 \pm 8.7^{\mathrm{b}}$ & $60.7 \pm 8.3^{\mathrm{a}}$ & $<0.001$ \\
Mean $\pm \mathrm{SD}$ & & & & \\
\hline Log HCV-titer & $<615^{*}$ & $10.9 \pm 3.2^{\mathrm{a}}$ & $9.9 \pm 4.1^{\mathrm{a}}$ & $5.2 \pm 4.7^{\mathrm{b}}$ & $<0.001$ \\
\hline
\end{tabular}

Groups with similar letters are not different statistically. A $p$-value $<0.05$ was considered significant. M/W: Men/Women; PNALT: chronic hepatitis C with persistent normal alanine aminotrasferase; CLD: chronic liver disease; HCC: hepatocellular carcinoma. ${ }^{*}$ All cases were under detection limit $(<615 \mathrm{IU} / \mathrm{ml})$ and so they were not included in the statistical analysis (Kruskal-Wallis ANOVA). 


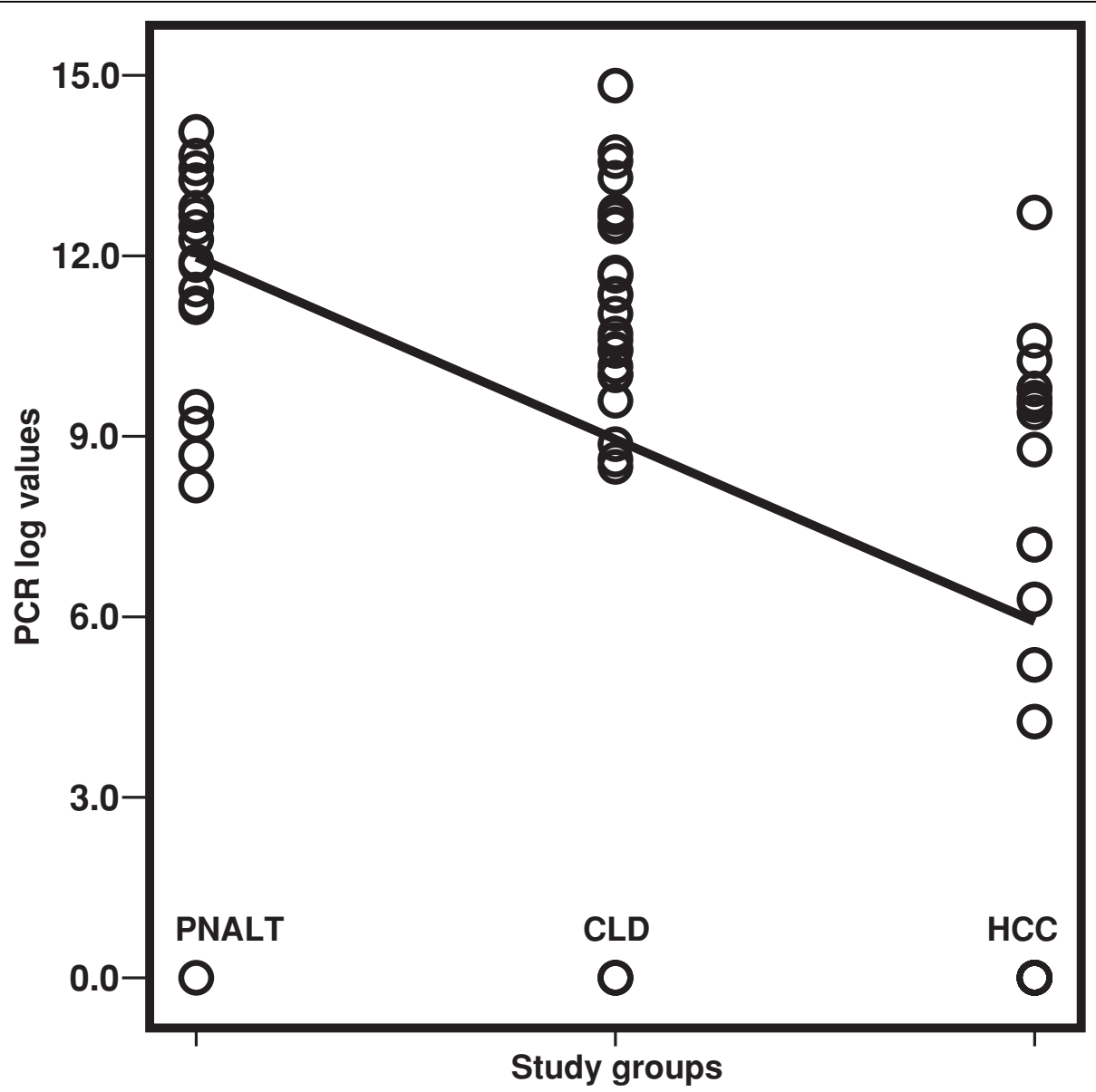

Figure 1 Scatter diagram of the distribution of log-HCV titer results among the different study groups. PNALT: Chronic hepatitis C with persistent normal alanine aminotrasferase; CLD: Chronic liver disease; HCC: hepatocellular carcinoma.

patients and control. On the other hand, IL-8 was significantly lower among HCC patients when compared to the other groups $(p<0.001)$; but with no significance between the other groups. The scatter diagrams of the studied cytokines in the different study groups are shown in Figures 2, 3, 4 and 5.

Correlation was done between the serum levels of the studied cytokines, liver enzymes and log-HCV titer. The liver enzymes, aspartate aminotransaminase (AST), alanine aminotransferase (ALT), and alkaline phosphatase, were significantly correlated with sTNFR-II, sIL-2R and IL-8, as exhibited in Table 3.

A statistically significant correlation was found between log-HCV RNA, sTNFR-II and IL-8 ( $p=0.06$ and 0.000 ) respectively, whereas sIL-2R and sFas did not show any significant difference in relation to log- $\mathrm{HCV}$ titer.

Moreover, correlation studies revealed a significant correlation between sFas, in the one hand, and sTNFRII or IL-2R, in the other hand ( $p=0.01$ and 0.000 ,

Table 2 Serum levels of sFas, sTNFR-II, sIL-2R and IL-8 in the different study groups.

\begin{tabular}{lccccc}
\hline $\begin{array}{l}\text { Cytokines } \\
\text { (pg/ml) }\end{array}$ & Control & PNALT & CLD & HCC & p-value \\
\hline SFas & $316 \pm 62.5^{\mathrm{b}}$ & $605.82 \pm 304^{\mathrm{ab}}$ & $814.94 \pm 362^{\mathrm{a}}$ & $762.18 \pm 437^{\mathrm{a}}$ & $<0.001$ \\
\hline STNF-RII & $375.26 \pm 58.4^{\mathrm{ab}}$ & $268.58 \pm 129^{\mathrm{b}}$ & $315.27 \pm 133.5^{\mathrm{b}}$ & $480.16 \pm 154.4^{\mathrm{a}}$ & $<0.001$ \\
\hline SIL-2Ra & $639.84 \pm 78.7^{\mathrm{b}}$ & $710.10 \pm 422^{\mathrm{b}}$ & $845.38 \pm 385.2^{\mathrm{ab}}$ & $1372.58 \pm 779.6^{\mathrm{a}}$ & 0.001 \\
\hline IL-8 & $345.84 \pm 75.6^{\mathrm{a}}$ & $350.7 \pm 53.6^{\mathrm{a}}$ & $352.33 \pm 98.3^{\mathrm{a}}$ & $228.61 \pm 51.1^{\mathrm{b}}$ & $<0.001$ \\
\hline
\end{tabular}

Values are expressed as mean \pm SD. Groups with similar letters are not statistically different. A $p$-value $<0.05$ was considered significant; PNALT: chronic hepatitis $C$ with persistent normal alanine aminotrasferase; CLD: chronic liver disease; HCC: hepatocellular carcinoma. 


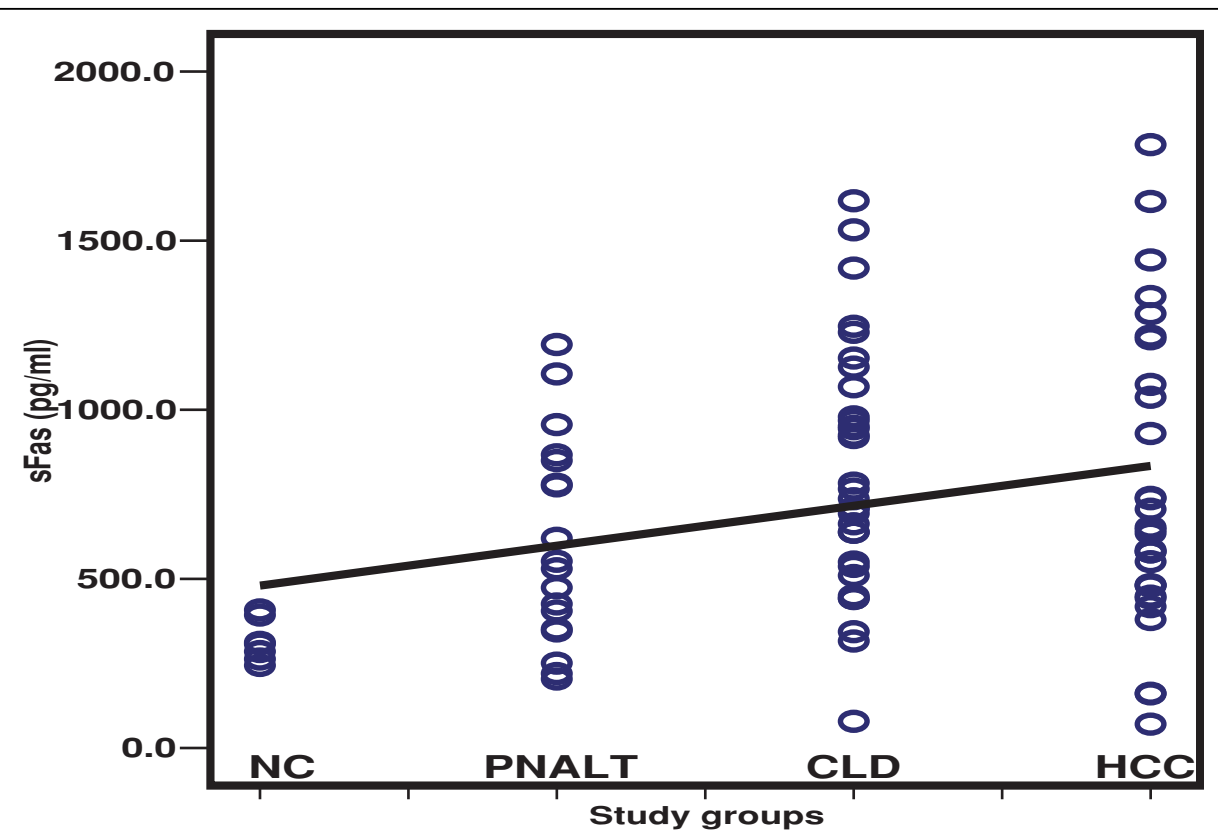

Figure 2 Scatter diagram representing the distribution values of sFas in the different study groups. NC: normal controls; PNALT: Chronic hepatitis C with persistent normal alanine aminotrasferase; CLD: Chronic liver disease; HCC: hepatocellular carcinoma.

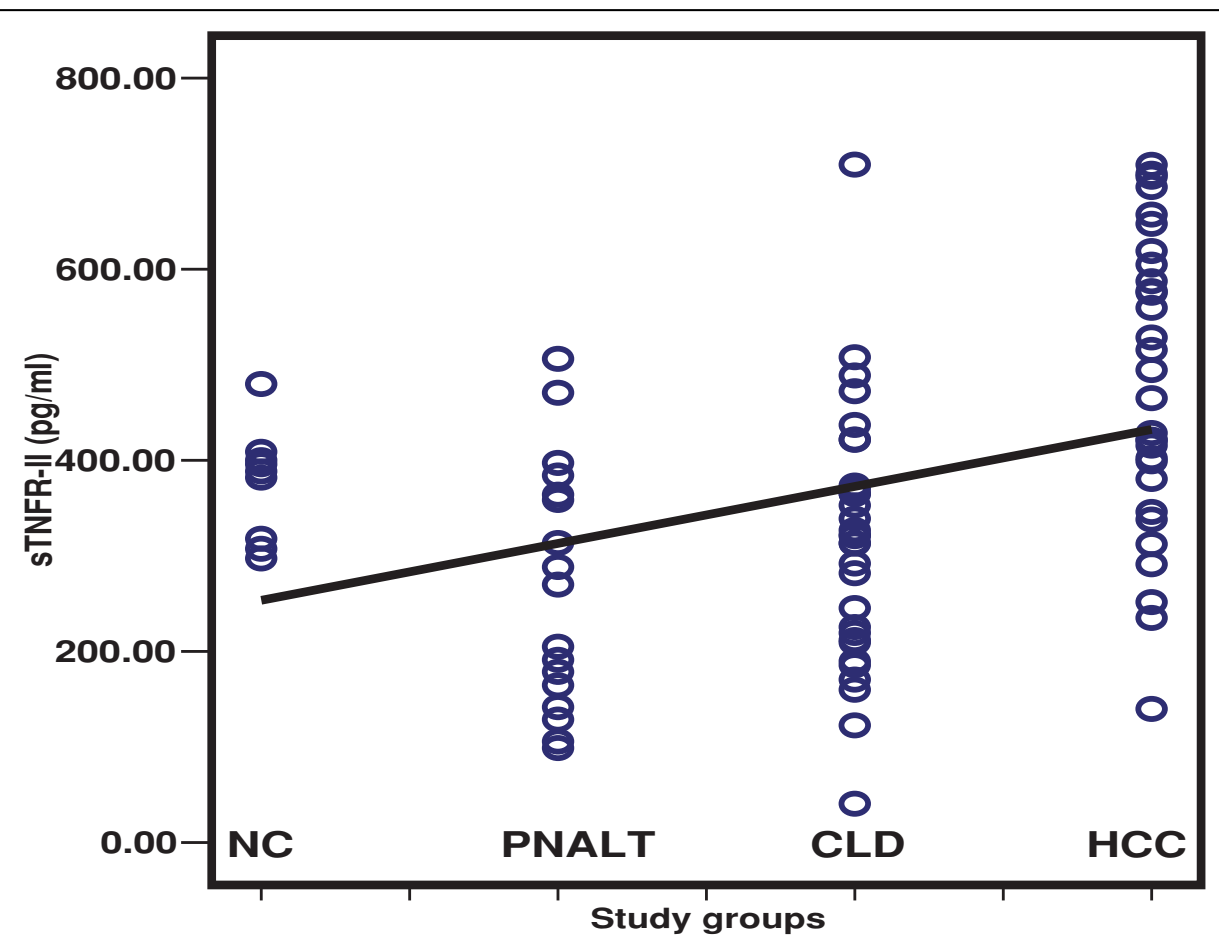

Figure 3 Scatter diagram representing the distribution values of sTNFR-II in the different study groups. NC: normal controls; PNALT: Chronic hepatitis C with persistent normal alanine aminotrasferase; CLD: Chronic liver disease; HCC: hepatocellular carcinoma. 


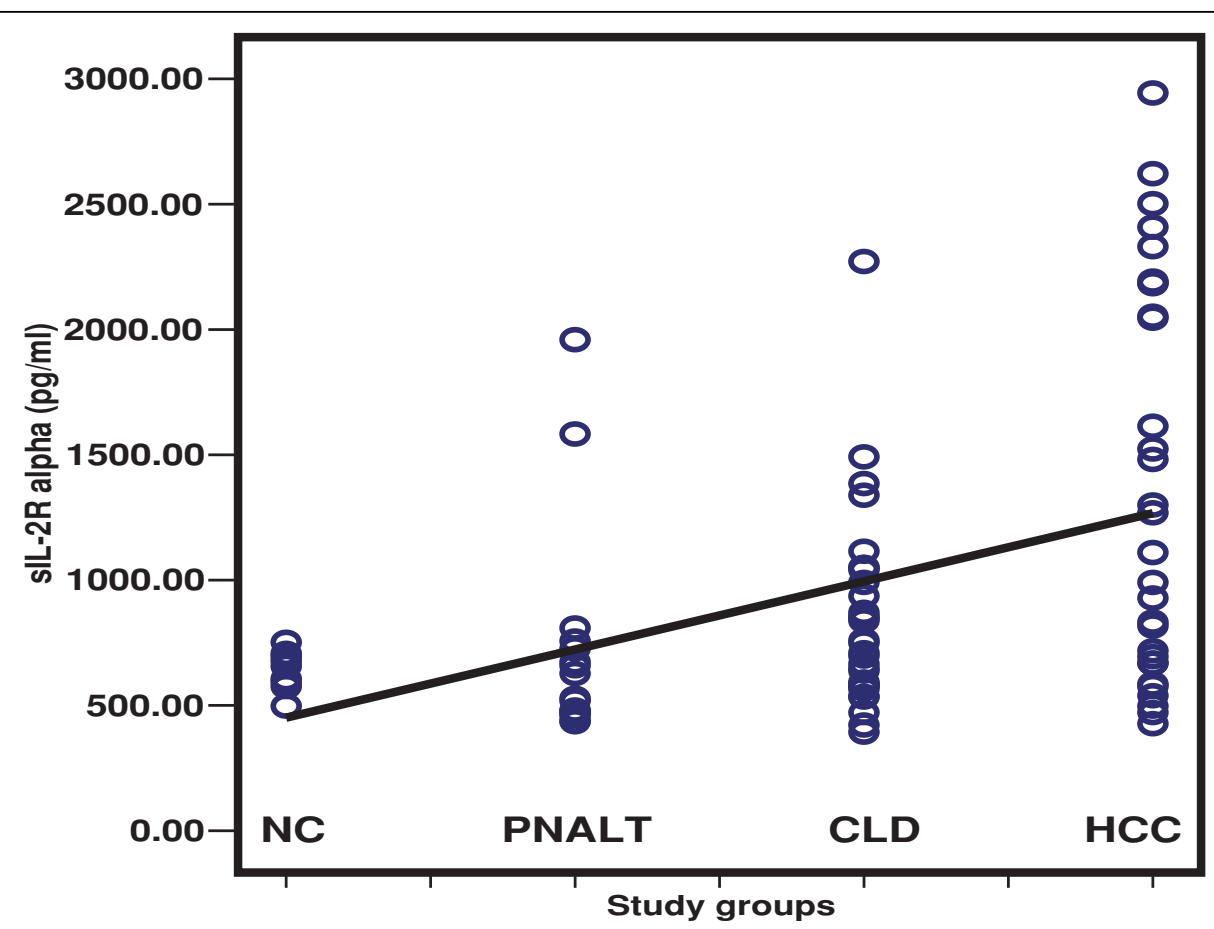

Figure 4 Scatter diagram representing the distribution values of sIL-2R $\alpha$ in the different study groups. NC: normal controls; PNALT: Chronic hepatitis C with persistent normal alanine aminotrasferase; CLD: Chronic liver disease; HCC: hepatocellular carcinoma.

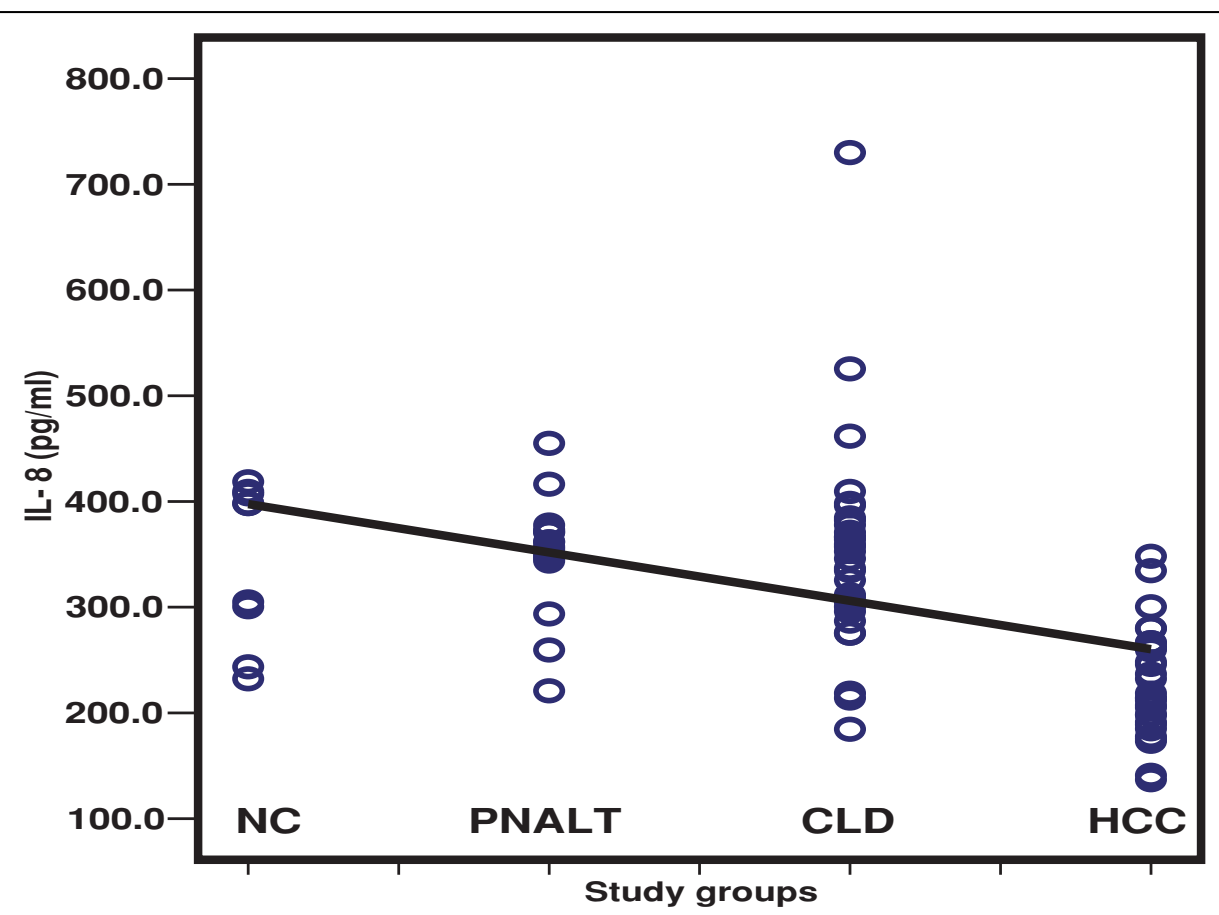

Figure 5 Scatter diagram representing the distribution values of IL-8 in the different study groups. NC: normal controls; PNALT: Chronic hepatitis C with persistent normal alanine aminotrasferase; CLD: Chronic liver disease; HCC: hepatocellular carcinoma. 
Table 3 Correlation of different markers, liver enzymes showing Pearson's $r$ value and $p$-values

\begin{tabular}{|c|c|c|c|c|c|c|c|}
\hline Labs & ALT & ALP & log-HCV titer & sFas & sTNFR-II & IL-2R & IL-8 \\
\hline AST & $\begin{array}{c}0.55 \\
(0.000)\end{array}$ & $\begin{array}{c}0.497 \\
(0.000)\end{array}$ & $\begin{array}{l}-0.481 \\
(0.000)\end{array}$ & $\begin{array}{c}0.127 \\
(0.3)\end{array}$ & $\begin{array}{c}0.265 \\
(0.029)\end{array}$ & $\begin{array}{c}0.332 \\
(0.006)\end{array}$ & $\begin{array}{l}-0.415 \\
(0.000)\end{array}$ \\
\hline ALT & & $\begin{array}{c}0.590 \\
(0.000)\end{array}$ & $\begin{array}{c}0.027 \\
(0.828)\end{array}$ & $\begin{array}{c}0.338 \\
(0.002)\end{array}$ & $\begin{array}{c}0.253 \\
(0.021)\end{array}$ & $\begin{array}{c}0.392 \\
(0.000)\end{array}$ & $\begin{array}{l}-0.269 \\
(0.014)\end{array}$ \\
\hline$\overline{A L P}$ & & & $\begin{array}{c}-0.218 \\
(0.083)\end{array}$ & $\begin{array}{c}0.081 \\
(0.5)\end{array}$ & $\begin{array}{c}0.342 \\
(0.004)\end{array}$ & $\begin{array}{c}0.374 \\
(0.002)\end{array}$ & $\begin{array}{l}-0.488 \\
(0.000)\end{array}$ \\
\hline log-HCV titer & & & & $\begin{array}{l}0.006 \\
(0.96)\end{array}$ & $\begin{array}{l}-0.220 \\
(0.067)\end{array}$ & $\begin{array}{l}-0.170 \\
(0.15)\end{array}$ & $\begin{array}{c}0.488 \\
(0.000)\end{array}$ \\
\hline sFas & & & & & $\begin{array}{c}0.276 \\
(0.010)\end{array}$ & $\begin{array}{c}0.403 \\
(0.000) \\
\end{array}$ & $\begin{array}{l}-0.139 \\
(0.199) \\
\end{array}$ \\
\hline sTNFR-II & & & & & & $\begin{array}{c}0.598 \\
(0.000)\end{array}$ & $\begin{array}{l}-0.304 \\
(0.004)\end{array}$ \\
\hline IL-2R & & & & & & & $\begin{array}{l}-0.236 \\
(0.028)\end{array}$ \\
\hline
\end{tabular}

Correlation is significant at the level of $\alpha<0.05$. The $p$-value appears within brackets. AST - aspartate aminotransaminase; ALT - alanine aminotransferase; ALP alkaline phosphatase.

respectively); but not with IL-8. The sTNFR-II was significantly correlated with sFas, IL-2R or IL-8 ( $\mathrm{p}=0.01$, 0.000 and 0.004 , respectively). IL-2R was significantly correlated with either sFas or IL-8 ( $p=0.000$ and 0.02 , respectively). IL- 8 was negatively correlated with sTNFR-II or IL-2R ( $p=0.000$ and 0.02 , respectively).

In the present study, levels of AFP among HCC patients were $\geq 200 \mathrm{ng} / \mathrm{ml}$ in 9 patients, whereas 11 patients had levels $<200 \mathrm{ng} / \mathrm{ml}$. There was no statistically significant difference when the levels of AFP were assessed against the serum levels of any of the studied cytokines.

Receiving operating characteristic (ROC) analysis curves and the corresponding area under the curve were calculated for providing the accuracy of the cytokines in differentiating between the different groups under consideration. Sensitivity (i.e., true positive rate), specificity (i.e., true negative rate), positive predictive value, negative predictive value and cutoff values showing the best equilibrium between sensitivity and specificity were evaluated. ROC curve and best cutoff values were calculated for patients with PNALT and HCC because there was no good discrimination between the other groups. ROC curve values for sTNFR-II and IL-8 among PNALT and HCC patients yielded a cutoff of $398 \mathrm{pg} / \mathrm{ml}$ and $345 \mathrm{pg} /$ $\mathrm{ml}$, respectively, as shown in Table 4, and Figures 6 and 7. ROC curve for IL-2R and sFas is shown in Figure 6.

Further analyses on the cytokines in HCC and PNALT patients are shown in Table 5 . Only sTNFR-II and IL-8 levels among patients with PNALT and HCC were analyzed. There were no satisfactory cutoff values for either IL-2R or sFas for both specificity and sensitivity, i.e., one on the expense of the other as evident by the ROC curve.

Among the HCC patients, 22/30 (73.3\%) had mean sTNFR-II levels of $\geq 398 \mathrm{pg} / \mathrm{ml}$, whereas only $2 / 17$
(11.8\%) cases with PNALT had this value with a highly significant difference $(p=0.000)$. Regarding IL-8, 29/30 (96.7\%) HCC patients had IL-8 level < 345 pg/ml compared to only $4 / 17$ cases with PNALT, whereas most PNALT patients had IL- $8 \geq 345 \mathrm{pg} / \mathrm{ml}(p=0.000)$. When both sTNFR-II and IL- 8 were combined together, all HCC cases $100 \%$ had either sTNFR-II $\geq 398 \mathrm{pg} / \mathrm{ml}$ or IL- $8<290 \mathrm{pg} / \mathrm{ml}(p=0.000)$ and $21 / 30(70 \%) \mathrm{HCC}$ had sTNFR-II $\geq 398 \mathrm{pg} / \mathrm{ml}$ and IL- $<290 \mathrm{pg} / \mathrm{ml}$ compared to none of PNALT cases $(p=0.000)$. In this vein, combined assessment of both sTNFR-II and IL- 8 at a cutoff of $\geq 398 \mathrm{pg} / \mathrm{ml}$ and $<290 \mathrm{pg} / \mathrm{ml}$, respectively, would be better in the diagnosis of HCC than either of them individually.

\section{Discussion}

HCC generally develops following an orderly progression from cirrhosis to dysplastic nodules to early cancer development, which can be reliably cured if discovered before the development of vascular invasion [34]. Early detection of HCC in those patients provides the best

Table 4 ROC curve values for sTNFR-II and IL-8 in PNALT and HCC patients

\begin{tabular}{lccc}
\hline ROC values & sTNF-RII $\geq \mathbf{3 9 8}$ & IL-8 $\geq \mathbf{3 4 5}$ & $\begin{array}{c}\text { TNFR-II } \geq \mathbf{3 9 8} \\
\text { or IL-8 }<\mathbf{2 9 0}\end{array}$ \\
\hline Sensitivity & $73.3 \%$ & $96.7 \%$ & $100 \%$ \\
\hline Specificity & $88.2 \%$ & $76.5 \%$ & $70.6 \%$ \\
\hline AUC & 0.849 & 0.588 & 0.794 \\
\hline NPV & $65.2 \%$ & $92.2 \%$ & $100 \%$ \\
\hline PPV & $91.7 \%$ & $87.9 \%$ & $85.7 \%$ \\
\hline
\end{tabular}

ROC - receiving operating characteristic; AUC - area under the curve; NPV negative predictive value; PPV - positive predictive value; PNALT: Chronic hepatitis $C$ with persistent normal alanine aminotrasferase. HCC: hepatocellular carcinoma. 


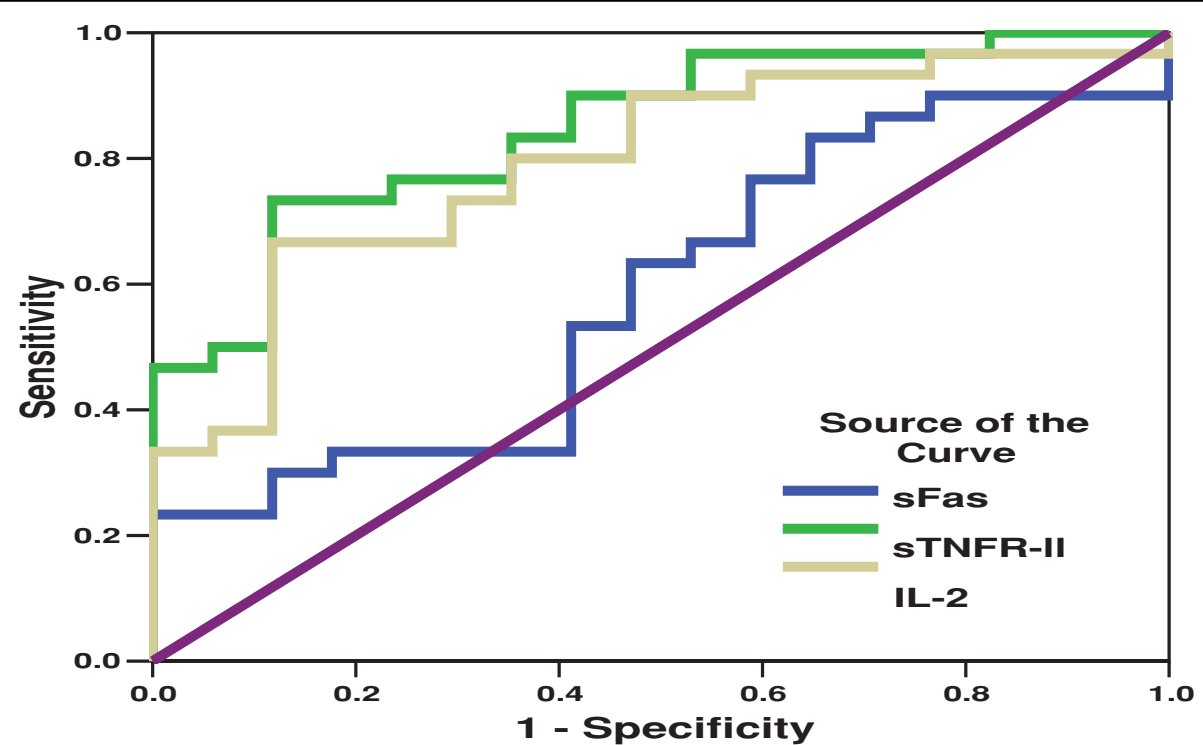

Figure 6 ROC (Receiving operating characteristic) curve showing sFas, sTNFR-II and IL-2R $\alpha$ in PNALT. Chronic hepatitis C with persistent normal alanine aminotrasferase) versus HCC (hepatocellular carcinoma) patients.

chance for a curative treatment, but AFP levels are frequently normal in patients with small HCC and are not elevated in a significant proportion of patients with early-stage, potentially curable HCC.

Elevated concentrations of cytokines represent a characteristic feature of CLD, regardless of the underlying etiology, and may represent a consequence of liver dysfunction instead of an inflammatory disorder [35]. Cytokines imbalance between T-helper 1 (Th1) and T-helper 2 (Th2) can prolong inflammation, leading to necrosis, fibrosis and CLD [36] in addition to the development and progression of HCC [37]. Cytokine production is thought to play an important role in the recruitment of

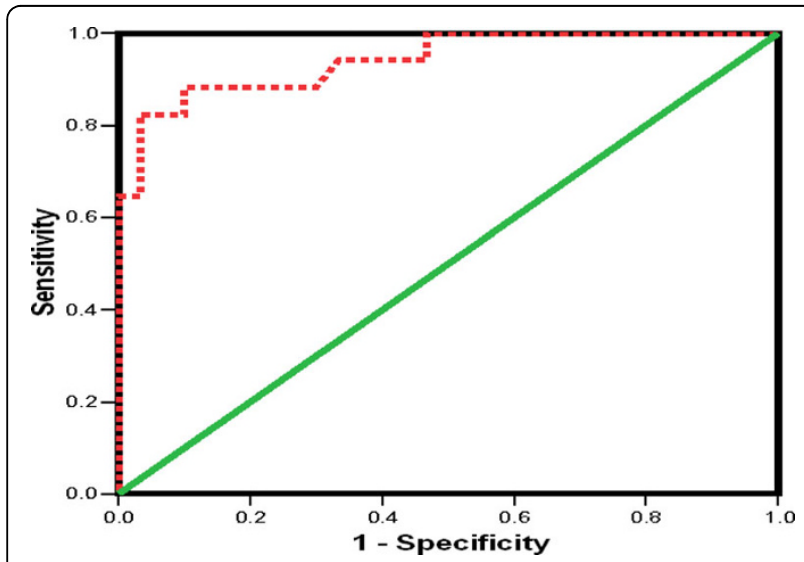

Figure 7 ROC (Receiving operating characteristic) curve showing IL-8 in PNALT (chronic hepatitis C with persistent normal alanine aminotrasferase) versus HCC (hepatocellular carcinoma) patients. tumor associated inflammatory cells, induction of angiogenesis and direct modulation of tumor cell proliferation $[38,39]$. The cytokines studied in this work were carefully chosen to include cytokines of the Th1 repertoire (IL-2R and sTNFR-II), in addition to one of the important pro-inflammatory cytokines (IL-8), and other factors as sFas.

In the present study, liver function tests were significantly elevated whereas $\log$ - HCV titer was significantly lower in HCC patients $(p<0.001)$ when compared to PNALT and CLD patients. In agreement with our findings, HCC group had the highest values (86.3\%) for various concurrently-measured liver function tests,

Table 5 sTNFR-II and IL-8 levels in PNALT and HCC cases

\begin{tabular}{|c|c|c|c|}
\hline $\begin{array}{l}\text { Cytokines (pg/ } \\
\mathrm{ml} \text { ) }\end{array}$ & PNALT, N = 17 & $\mathrm{HCC}, \mathrm{N}=30$ & $p$-value \\
\hline sTNFR- $\| \geq 398$ & $2(11.8 \%)$ & $22(73 \%)$ & 0.000 \\
\hline sTNFR-II $<398$ & $15(88.2 \%)$ & $6(27 \%)$ & 0.000 \\
\hline IL-8 $<345$ & $4(23.5 \%)$ & 29 (97\%) & 0.000 \\
\hline IL-8 $\geq 345$ & $13(76.5 \%)$ & $1(3.3 \%)$ & 0.000 \\
\hline $\begin{array}{l}\text { TNFR- II } \geq 398 \text { or } \\
\text { IL-8 <290. Either } \\
+ \text { ve }\end{array}$ & $5(29.4 \%)$ & $30(100 \%)$ & 0.000 \\
\hline $\begin{array}{l}\text { TNFR-II } \geq 398 \\
\text { and IL-8 }<290 \\
\text { Both - ve }\end{array}$ & $12(70.6 \%)$ & $0(0 \%)$ & 0.000 \\
\hline $\begin{array}{l}\text { TNFR- } \| \geq 398 \\
\text { and IL-8<290. } \\
\text { Both }+ \text { ve }\end{array}$ & $0(0 \%)$ & $21(70 \%)$ & 0.000 \\
\hline Others & 17 (100\%) & $9(30 \%)$ & 0.000 \\
\hline
\end{tabular}

PNALT: chronic hepatitis C with persistent normal alanine aminotrasferase; HCC: hepatocellular carcinoma. 
significant higher values of AST/ALT, ALT, AST (each, $p<0.001)$ than cirrhotic patients as previously reported [40]. On the other hand, HCV levels were markedly higher in non-cancerous liver than in HCC $(p=0.001)$ [41]. Moreover, comparing HCV titers of four HCC isolates and surrounding cirrhotic liver tissues in two anti$\mathrm{HCV}$ positive patients; the copy numbers of $\mathrm{HCV}$-RNA were $1 \times 10^{6}$ and $4 \times 10^{6} / \mathrm{gm}$ wet weight of $\mathrm{HCC}$, and 8 $\times 10^{7}$ and $3.2 \times 10^{8} / \mathrm{gm}$ wet weight of cirrhotic liver tissues from patient-1 and -2 , respectively [42]. The present study showed that men had higher log-HCV RNA titer than that detected in women; then, a strong evidence is provided in favour of a higher HCV clearance rate in women compared with that in men [43].

Fas (APO-1 or CD95) is a cell-surface receptor that transduces apoptotic signals from Fas ligand (Fas-L) [44]. Apoptosis is tightly regulated throughout a variety of mechanisms, one of which is postulated to be the production of soluble forms of Fas (sFas) that normally binds to Fas- $\mathrm{L}$, thus blocking the signaling of the membrane-bound form of Fas. Peripheral blood mononuclear cells in HCV infection exhibit decreased susceptibility to Fas-L induced cell death. This may signify a mean by which HCV escapes immune surveillance; however, it would be worth a further investigation on this phenomenon. The sFas appeared to increase in advanced stages of HCV-induced liver disease, as a result of host-related immunological factors [45]. In the present series, the mean values of sFas were significantly higher in $\mathrm{HCC}$ patients compared to the other groups $(p<0.001)$. This could be explained by the role of sFas in the inhibition of apoptosis, progression to end stage liver damage, and subsequent development of HCC. Similarly, a significant elevation of serum levels of sFas in HCC patients compared with liver cirrhosis and healthy control was previously reported [46]. Previous studies [47,48] have reported mRNA encoding secreted sFas in a number of hepatitis and HCC cases indicating that sFas may function as an inhibitor of the Fas/Fas-L system and escape of tumor cells from immune surveillance may then occur. In chronic hepatitis, sFas was correlated with the severity of disease [15] and its expression can illustrate the mechanism of liver injury caused by death receptors throughout the multistep process of fibrosis/carcinogenesis. So, the increased incidence of HCC is correlated not only with the higher degree of hepatic fibrosis, but also with the lower expression of Fas protein [49].

The rate of progression to end-stage liver disease might be related to an up-regulation of the TNF- $\alpha /$ Fas pathways and an age-dependent host response [50]. Proinflammatory TNF- $\alpha$ released by host and tumor cells is an important factor involved in initiation, proliferation, angiogenesis as well as metastasis of various cancer types [51]. Activities of TNF- $\alpha$ are mediated through
TNFR-I and TNFR-II [52]. Our results showed that levels of sTNFR-II were elevated in patients with PNALT, CLD and HCC with a significant difference between HCC in relation to the other two groups $(p<$ $0.001)$. These results are in agreement with previous published results $[13,29,53]$, where it was found that sTNFR-II $\alpha$ were closely correlated with disease progression in chronic HCV infection. Enhanced TNF- $\alpha$ and TNFRs in chronic HCV infection may reflect the histological activity of the disease and TNFRs up-regulation might modify host response and potentially contribute to liver damage [54].

IL-2 is a cytokine produced by $\mathrm{T}$ cells in response to inflammatory stimuli. It induces the surface expression of IL-2 receptor (IL-2R) and, consequently, the production of its soluble form, sIL-2R. The excess of sIL-2R is capable of binding IL-2 and causes the inhibition of an appropriate immune response. IL-2R is the protein that mediates the action of IL-2, which is normally not displayed at a significant number on $\mathrm{T}$ and $\mathrm{B}$ cell surfaces. Stimulation of the immune system causes two IL-2R changes: more molecules of "IL-2R" expressed on the cell plasma membrane and sIL-2R $\alpha$ is released by the activated cells into the surrounding fluid [55]. Our results showed that levels of IL-2R $\alpha$ were elevated in all studied patients with a statistically significant difference in HCC patients when compared to those with PNALT $(p=0.001)$. This could be attributed to the binding of IL-2 due to excess of its receptor and thus inducing an inhibition of the appropriate immune response with subsequent progression of chronic liver disease and the development of HCC. Previous results $[13,17,56]$ are in agreement with ours, where it is was shown that serum levels of sIL-2R are correlated with the histological severity of liver damage in HCV patients, which may be used as a marker in patients at high risk of getting HCC as the highest levels of soluble IL-2R occurred in those patients. The sIL-2R may be an important marker for assessing the phase of active chronic hepatitis and the degree of liver damage [57]. High sIL-2R levels, found in patients with chronic HBV [58,59], were related to the activity of the disease rather than to the virus replication; thus, those levels may be a useful marker of T-cells immune response. In contrast to our results, it was concluded that IL-2R was not detectable in HCC patients in comparison to patients with chronic hepatitis and liver cirrhosis [60]. Regarding the levels of IL-2R in patients with $\mathrm{HCC}$, and in agreement with our findings, there was no statistically significant difference $(p=0.62)$ between its values in men and women [55].

IL-8 is a chemoattractant cytokine which is produced after stimulation with numerous exogenous and endogenous agents. Viruses induce IL-8 production leading to enhanced viral RNA replication and cytopathic 
effects. Furthermore, evidence was provided that induction of that interleukin was able to attenuate the IFN- $\alpha$ mediated inhibition of viral replication [61]. In the current study, levels of IL-8 were significantly lower in HCC patients than in the other groups $(p<0.001)$. On the contrary, other results found that serum IL-8 levels were markedly elevated in most HCC patients compared with healthy subjects [62] and was found to be over expressed in the HCC tumor cells compared with the non-tumorous livers [63]. Furthermore, multivariate analyses revealed that the levels of the interleukin under consideration may play an important role in the progression and dissemination of HCC and is an independent predictor of long-term survival among those patients. High-serum level of that cytokine may reflect active angiogenesis and rapid tumor growth in HCC. Therefore, targeting IL- 8 can represent a potential approach to control angiogenesis and invasion of HCC [62]. In agreement with our results, there was no significant correlation between serum concentration of that cytokine and patient gender $(p=0.215)$ [63].

The present series showed that HCV viral load was significantly correlated with sTNFR-II and IL-8. The production of the latter was found to enhance viral RNA replication [61], thus the low levels of the interleukin in our HCC patients are in accordance with the low $\mathrm{HCV}$ viral load. Moreover, there is a good correlation between reduction in virus load and IL- 8 level which may indicate that it is related to viral infection rather than to hepatocarcinogenesis.

In the current series, the studied cytokines were significantly correlated to each other. The sFAS was positively correlated with sTNFR-II and IL-2R; sTNFR-II positively correlated with IL-2R and negatively with IL8; lastly IL-2R and IL-8 were negatively correlated.

Th1 cytokines, which include IL-2R and sTNFR-II, are in favor of an effective immune response against viral infection, whereas Th2 (represented by IL- 8 in our study), is in favor of progressive inflammation, continuous cell injury and persistent HCV infection [64].

The depicted correlations could highlight the imbalance between pro- and anti-inflammatory cytokines among patients with CLD and HCC. Furthermore, the rate of progression of $\mathrm{CHC}$ to end-stage liver disease might be related to an up-regulation of the TNF- $\alpha / F a s$ pathways [50].

Analysis of sTNFR-II and IL-8 by ROC curves revealed satisfactory values regarding sensitivity and specificity at a cutoff value of $\geq 398 \mathrm{pg} / \mathrm{ml}$ and $\leq 290 \mathrm{pg} /$ $\mathrm{ml}$, respectively, when both markers were combined. Therefore, a simultaneous assessment of both sTNFR-II and IL- 8 would be beneficial for the diagnosis of HCC; in fact, they were capable of differentiating between patients with PNALT and HCC - hence, an early detection of HCC among apparently healthy patients with PNALT levels. Nonetheless, these values must be evaluated on a larger scale of patients with various stages of CLD and HCC, in order to be used as new markers for an early detection of HCC.

\section{Conclusions}

Cytokines are involved during disease progression in $\mathrm{HCV}$-infected patients. Early detection of HCC patients is essential in the course of HCV associated CLD and its sequels. IL-2R $\alpha$, TNFR-II and sFas were significantly higher, whereas IL-8 values were significantly lower in HCC patients in comparison to the other groups. Our preliminary data revealed that exclusion of HCC among PNALT patients could be predicted when both sTNFRII and IL- 8 are assessed together at a cutoff value $\geq 389$ $\mathrm{pg} / \mathrm{ml}$ and IL-8 $<290 \mathrm{pg} / \mathrm{ml}$, respectively. Nevertheless, further studies with a larger sample size are mandatory to underline the accuracy of our findings before their application at the population level.

\section{Methods}

\section{Study population}

Peripheral blood samples from 79 adult patients with HCV related CLD (with or without HCC) and from 9 healthy subjects (served as the control group) were collected, between April 2005 and June 2006, in the specialized liver clinic of the National Cancer Institute (NCI), Faculty of Medicine, Cairo University, before receiving any treatment. All samples were analyzed for cytokine quantitation. The study was approved by the Investigation and Ethics Committee of the hospital and a written consent was obtained from all the persons involved.

The group size included 30 patients with HCC besides CLD diagnosed by abdominal ultrasonography, triphasic $\mathrm{CT}$ abdomen, serum AFP and confirmed histomorphologically; 32 patients with $\mathrm{CHC}$ with elevated ALT levels; 15 patients with fibrosis stage ranged from F1-F4; 7 patients with histopathological evidence of cirrhosis (F5-F6); 17 patients patients with PNALT levels for at least 6 months, no organomegaly on ultrasonographic examination and fibrosis stage less than F2, i.e., mild fibrosis.

The nine above mentioned healthy subjects (control group) were 50.9 years old (mean) \pm 4.6 (standard deviation), with male/female ratio of $7 / 2$, with no clinical or biochemical evidence of liver disease or known medical illness at recruitment and with normal abdominal ultrasonography. All controls were negative for HBV and $\mathrm{HCV}$ as evidenced by negative serological markers and negative PCR for HBV and HCV.

Exclusion criteria were: patients with HBV, history of drug hepatotoxicity, autoimmune liver disease and metabolic liver diseases. 


\section{Study design}

A detailed history, clinical assessment, biochemical liver profile, abdominal ultrasonography were done to all study groups in addition to serologic testing, virological assay by quantitative PCR (VERSANT HCV RNA 3.0 Assay), HCV genotyping using INNO-LiPA III provided by Innogenetics [65] and histolopathological examination among CLD disease patients to determine the histological activity index (HAI) using the Ishak scoring system [66].

\section{Cytokine assay}

Cytokines were assayed using quantitative ELISA plate method: sIL-2R $\alpha$, IL-8, sTNFR-II and sFas using kits provided by Quantikine (R\&D Systems, Inc.614 McKinly Place N.E. MN 55413, USA).

\section{Statistical analysis}

The SPSS software package (version 15) was used. Mean \pm SD (standard deviation) were computed for the quantitative data. The non-parametric t-test equivalent (Mann-Whitney test) and the non-parametric ANOVA (Kruskal-Wallis test) were used to compare means of, respectively, two or more than two independent groups. Fisher's exact and chi-square tests were used to validate the hypothesis of proportional independency. Correlation analysis was used to detect the association between quantitative data.

\section{Acknowledgements}

The authors would like to thank Prof. Dr. Nelly H. Ali El-Din for her efforts in doing the statistical analysis. This work was supported by National Cancer Institute, Cairo University funding office and by the USDA/FAS/ICD/RSED project (Number BIO8-002-009). We would like to thank Professor Dr. Rogério Monteiro (Associate Editor of Comparative Hepatology) for his sincere and fruitful help throughout mending the manuscript.

\section{Author details}

${ }^{1}$ Virology and Immunology Unit, Cancer Biology, National Cancer Institute, Cairo University, Cairo, Egypt. ²Pathology Department, National Cancer Institute, Cairo University, Cairo, Egypt. ${ }^{3}$ Tropical Medicine Department, Faculty of Medicine, Cairo University, Cairo, Egypt. ${ }^{4}$ Biochemistry Department, Faculty of Science, Cairo University, Giza, Egypt

\section{Authors' contributions}

A-RNZ: conception and design of the study, drafting the manuscript, revising it critically for important intellectual content. HMAE-D: analysis and interpretation of data, drafting the manuscript, revising it critically for important intellectual content, helped in the study supervision. AAB: Revision of histological findings of the studied cases, helped in the study supervision. NAZ: Provided samples, and collection of data. WSM: Participated in the cytokine assaying. SHE-M: Participated in the practical part and drafting the manuscript. SKG: Participated in the practical part and drafting the manuscript. GE: Provided samples, participation in the study design. All authors read and approved the final manuscript.

\section{Competing interests}

The authors declare that they have no competing interests.

Received: 4 April 2009

Accepted: 5 January 2010 Published: 5 January 2010
References

1. Llovet JM, Burroughs A, Bruix J: Hepatocellular carcinoma. Lancet 2003, 362:1907-1917.

2. El-Serag $H B$, Mason $A C$ : Rising incidence of hepatocellular carcinoma in the United States. N Engl J Med 1999, 340:745-750.

3. Shibuya K, Yano E: Regression analysis of trends in mortality from hepatocellular carcinoma in Japan, 1972-2001. Int J Epidemiol 2005, 34:397-402.

4. Bruix J, Barrera JM, Calvet X, Ercilla G, Costa J, Sanchez-Tapias JM, Ventura M, Vall M, Bruguera M, Bru C, et al: Prevalence of antibodies to hepatitis $C$ virus in Spanish patients with hepatocellular carcinoma and hepatic cirrhosis. Lancet 1989, 2:1004-1006.

5. Colombo M, Kuo G, Choo QL, Donato MF, Del Ninno E, Tommasini MA, Dioguardi N, Houghton M: Prevalence of antibodies to hepatitis C virus in Italian patients with hepatocellular carcinoma. Lancet 1989, 2:10061008.

6. Shepard CW, Finelli L, Alter MJ: Global epidemiology of hepatitis C virus infection. Lancet Infect Dis 2005, 5:558-567.

7. Frank C, Mohamed MK, Strickland GT, Lavanchy D, Arthur RR, Magder LS, El Khoby T, Abdel-Wahab Y, Aly Ohn ES, Anwar W, Sallam I: The role of parenteral antischistosomal therapy in the spread of hepatitis $C$ virus in Egypt. Lancet 2000, 355:887-891.

8. Nafeh MA, Medhat A, Shehata M, Mikhail NN, Swifee Y, Abdel-Hamid M, Watts S, Fix AD, Strickland GT, Anwar W, Sallam I: Hepatitis C in a community in Upper Egypt: I. Cross-sectional survey. Am J Trop Med Hyg 2000, 63:236-241.

9. Abdel-Aziz F, Habib M, Mohamed MK, Abdel-Hamid M, Gamil F, Madkour S, Mikhail NN, Thomas D, Fix AD, Strickland GT, Anwar W, Sallam I: Hepatitis C virus $(\mathrm{HCV})$ infection in a community in the Nile Delta: population description and HCV prevalence. Hepatology 2000, 32:111-115.

10. El-Sadawy M, Ragab H, el-Toukhy H, el-Mor Ael-L, Mangoud AM, Eissa MH, Afefy AF, el-Shorbagy E, Ibrahem IA, Mahrous S, Abdel-Monem A, Sabee El, Ismail A, Morsy TA, Etewa S, Nor Edin E, Mostafa Y, Abouel-Magd Y, Hassan Ml, Lakouz K, Abdel-Aziz K, el-Hady G, Saber M: Hepatitis C virus infection at Sharkia Governorate, Egypt: seroprevalence and associated risk factors. J Egypt Soc Parasitol 2004, 34(Suppl 1):367-384.

11. Deuffic-Burban S, Mohamed MK, Larouze B, arrat F, Valleron AJ: Expected increase in hepatitis C-related mortality in Egypt due to pre-2000 infections. J Hepatol 2006, 44:455-461.

12. Ahn J, Chung KS, Kim DU, Won M, Kim L, Kim KS, Nam M, Choi SJ, Kim HC, Yoon M, Chae SK, Hoe KL: Systematic identification of hepatocellular proteins interacting with NS5A of the hepatitis $C$ virus. J Biochem $\mathrm{Mol}$ Biol 2004, 37:741-748.

13. Zekri AR, Ashour MS, Hassan A, Alam El-Din HM, El-Shehaby AM, AbuShady MA: Cytokine profile in Egyptian HCV genotype-4 in relation to liver disease progression. World Journal of Gastroenterology 2005, 11:66246630.

14. Zekri AR, Haleem HA, Esmat GE, Bahnassy AA, El-Din HM, Hafez MM, Sharaby AF, Sharaf $H$, Zakaria MS: Immunomodulators, sFas and Fas-L as potential noninvasive predictors of IFN treatment in patients with HCV genotype-4. J Viral Hepatol 2007, 14:468-477.

15. Chen J, Zheng XH, Tang XP: [A comparative study of serum sFas in patients with hepatocellular cancer and chronic hepatitis]. Hunan Yi Ke Da Xue Xue Bao 2001, 26:173-174.

16. Sacco R, Leuci D, Tortorella C, Fiore G, Marinosci F, Schiraldi O, Antonaci S: Transforming growth factor beta1 and soluble Fas serum levels in hepatocellular carcinoma. Cytokine 2000, 12:811-814.

17. Izzo F, Cremona F, Delrio P, Leonardi E, Castello G, Pignata S, Daniele B, Curley SA: Soluble interleukin-2 receptor levels in hepatocellular cancer: a more sensitive marker than alfa fetoprotein. Ann Surg Oncol 1999, 6:178-185

18. Chuang E, Del Vecchio A, Smolinski S, Song XY, Sarisky RT: Biomedicines to reduce inflammation but not viral load in chronic HCV: what's the sense?. Trends Biotechnol 2004, 22:517-523.

19. Koulentaki M, Notas G, Petinaki E, Valatas V, Mouzas IA, Castanas E, Kouroumalis EA: Nitric oxide and pro-inflammatory cytokines in acute hepatitis B. Eur J Intern Med 2004, 15:35-38.

20. Choi J, Ou JHJ: Mechanisms of liver injury: III. Oxidative stress in the pathogenesis of hepatitis C virus. Am J Physiol Gastrointest Liver Physiol 2006, 290:G847-G851. 
21. Schwabe RF, Brenner DA: Mechanisms of liver injury: I.TNF-a- induced liver injury: role of IKK, JNK, ROS pathways. Am J Physiol Gastrointest Liver Physiol 2006, 290:G583-G589.

22. Akpolat N, Yahsi S, Godekmerdan A, Demirbag K, Yalniz M: Relationship between serum cytokine levels and histopathological changes of liver in patients with hepatitis B. World J Gastroenterol 2005, 11:3260-3263.

23. Odeh M, Sabo E, Srugo I, Oliven A: Relationship between tumor necrosis factor-a and ammonia in patients with hepatic encephalopathy due to chronic liver failure. Ann Med 2005, 37:603-612.

24. Falasca K, Ucciferri C, Dalessandro M, Zingariello P, Mancino P, Petrarca C, Pizzigallo $E$, Conti $P$, Vecchiet J: Cytokine patterns correlate with liver damage in patients with chronic hepatitis B and C. Ann Clin Lab Sci 2006, 36:144-150.

25. Cua IH, Hui JM, Bandara P, Kench JG, Farrell GC, McCaughan GW, George J: Insulin resistance and liver injury in hepatitis $C$ is not associated with virus-specific changes in adipocytokines. Hepatology 2007, 46:66-73.

26. Elsammak M, Refai W, Elsawaf A, Abdel-Fattah I, Abd Elatti E, Ghazal A: Elevated serum tumor necrosis factor alpha and ferritin may contribute to the insulin resistance found in HCV positive Egyptian patients. Curr Med Res Opin 2005, 21:527-534.

27. Kamal SM, Turner B, He Q, Rasenack J, Bianchi L, Al Tawil A, Nooman A, Massoud M, Koziel MJ, Afdhal NH: Progression of fibrosis in hepatitis $C$ with and without schistosomiasis: correlation with serum markers of fibrosis. Hepatology 2006, 43:771-779.

28. Nelson DR, Lim HL, Marousis CG, Fang JW, Davis GL, Shen L, Urdea MS, Kolberg JA, Lau JY: Activation of tumor necrosis factor a system in chronic hepatitis C virus infection. Dig Dis Sci 1997, 42:2487-2494.

29. Aderka D, Wysenbeek A, Engelmann H, Cope AP, Brennan F, Molad Y, Hornik V, Levo Y, Maini RN, Feldmann M, et al: Correlation between serum levels of soluble tumor necrosis factor receptor and disease activity in systemic lupus erythematosus. Arthritis Rheum 1993, 36:1111-1120.

30. Kallinowski B, Haseroth K, Marinos G, Hanck C, Stremmel W, Theilmann L, Singer MV, Rossol S: Induction of tumour necrosis factor (TNF) receptor type p55 and p75 in patients with chronic hepatitis $\mathrm{C}$ virus (HCV) infection. Clin Exp Immunol 1998, 111:269-277.

31. Zylberberg H, Rimaniol AC, Pol S, Masson A, De Groote D, Berthelot P, Bach JF, Bréchot C, Zavala F: Soluble tumor necrosis factor receptors in chronic hepatitis C: a correlation with histological fibrosis and activity. $J$ Hepatol 1999, 30:185-191.

32. Kaplanski G, Marin V, Maisonobe T, Sbai A, Farnarier C, Ghillani P, Thirion X, Durand JM, Harlé JR, Bongrand P, Piette JC, Cacoub P: Increased soluble p55 and p75 tumour necrosis factor-a receptors in patients with hepatitis C-associated mixed cryoglobulinaemia. Clin Exp Immunol 2002, 127:123-130

33. Kubo F, Ueno S, Hiwatashi K, Sakoda M, Kawaida K, Nuruki K, Aikou T: Interleukin 8 in Human Hepatocellular Carcinoma Correlates With Cancer Cell Invasion of Vessels But Not With Tumor Angiogenesis. Ann Surg Oncol 2005, 12:800-807.

34. Schwartz M, Roayaie $S$, Konstadoulakis M: Strategies for the management of hepatocellular carcinoma. Nat Clin Pract Oncol 2007, 4:424-432.

35. Tilg H, Wilmer A, Vogel W, Herold M, Nölchen B, Judmaier G, Huber C: Serum levels of cytokines in chronic liver diseases. Gastroenterology 1992, 103:264-274.

36. Jacobson-Brown $\mathrm{P}$, Neuman M: Th1/Th2 responses and the role of cytokines. Clin Biochem 2001, 34:167-171.

37. Budhu A, Wang XW: The role of cytokines in hepatocellular carcinoma. J Leukoc Biol 2006, 80:1197-1213.

38. Aref $S$, Menessy A: Correlation of soluble IL-2R and tumor necrosis factor $\alpha$ receptor (TNF- $\alpha$ R) levels with severity of chronic hepatitis $C$ liver injury. The Egypt J Hematol 1997, 22:327-340.

39. Quentmeier H, Dirks WG, Fleckenstein D, Zaborski M, Drexler HG: Tumor necrosis factor- $\alpha$ induced proliferation requires synthesis of granulocyte macrophage colony-stimulating factor. Exp Hematol 2000, 28:1008-10015.

40. Sugiyama M, Kanno T, Ohkubo A, Muto Y, Murata K, Ueno Y: The clinical usefulness of the molar ratio of branched-chain amino acids to tyrosine (BTR) in discriminating stage of chronic liver diseases. Rinsho Byori 1992, 40:673-678.

41. Young KC, Lin PW, Hsiao WC, Chang TT, Chang YC, Wu HL: Variation of hepatitis $C$ virus load, hypervariable region 1 quasispecies and CD81 hepatocyte expression in hepatocellular carcinoma and adjacent noncancerous liver. J Med Virol 2002, 68:188-196.
42. Park CK, Park TR, Kim YB, Kim HY, Yoo JY, Kim CH, Choo SH, Cho JM: Viral loads and E2/NS1 region sequences of hepatitis $C$ virus in hepatocellular carcinoma and surrounding liver. Korean J Intern Med 1997, 12:28-33.

43. Bakr I, Rekacewicz C, El Hosseiny M, Ismail S, El Daly M, El-Kafrawy S, Esmat G, Hamid MA, Mohamed MK, Fontanet A: Higher clearance of hepatitis C virus infection in females compared with males. Gut 2006, 55:1183-1187.

44. Nagata S: Apoptosis regulated by a death factor and its receptor: Fas ligand and Fas. Philos Trans R Soc Lond B Biol Sci 1994, 345:281-287.

45. Ozaslan E, Kiliçarslan A, Simşek H, Tatar G, Kirazli S: Elevated serum soluble Fas levels in the various stages of hepatitis $C$ virus-induced liver disease. $J$ Int Med Res 2003, 31:384-391.

46. Jodo S, Kobayashi S, Nakajima Y, Matsunaga T, Nakayama N, Ogura N, Kayagaki N, Okumura K, Koike T: Elevated serum levels of soluble Fas/ APO-1 (CD95) in patients with hepatocellular carcinoma. Clin Exp Immunol 1998, 112:166-171.

47. Pinkoski MJ, Brunner T, Green DR, Lin T: Fas and Fas ligand in gut and liver. Am J Physiol Gastrointest Liver Physiol 2000, 278:G354-G366.

48. Shiota G, Oyama K, Noguchi N, Takano Y, Kitaoka S, Kawasaki H: Clinical significance of serum soluble Fas ligand in patients with acute selflimited and fulminant hepatitis. Res Commun Mol Pathol Pharmacol 1998, 101:3-12.

49. El Bassiouny AE, El-Bassiouni NEl, Nosseir MMF, Zoheiry MMK, El-Ahwany EG, Salah F, Omran ZSO, Ibrahim RA: Circulating and Hepatic Fas Expression in HCV-Induced Chronic Liver Disease and Hepatocellular Carcinoma. Medscape J Med 2008, 10:130.

50. Macías J, Sánchez-Quijano A, Pineda JA, Abad MA, Rubio A, Rosa R, Leal M, Lissen $E$ : Minimal liver injury in chronic hepatitis $C$ virus infection is associated with low levels of soluble TNF-alpha/Fas receptors and acquisition in childhood. Liver 2001, 21:410-414

51. Luo JL, Maeda S, Hsu LC, Yagita H, Karin M: Inhibition of NF-kappaB in cancer cells converts inflammation- induced tumor growth mediated by TNFalpha to TRAIL-mediated tumor regression. Cancer Cell 2004, 6:297305.

52. Herbein G, O'Brien WA: Tumor necrosis factor (TNF)-alpha and TNF receptors in viral pathogenesis. Proc Soc Exp Biol Med 2000, 223:241-257.

53. Kakumu S, Okumura A, Ishikawa T, Yano M, Enomoto A, Nishimura H: Serum levels of IL-10, IL-15 and soluble tumour necrosis factor-alpha (TNF-alpha) receptors in type $\mathrm{C}$ chronic liver disease. Clin Exp Immunol 1997, 109:458-463.

54. Kallinowski B, Haseroth K, Marinos G, Hanck C, Stremmel W, Theilmann L: Induction of tumour necrosis factor (TNF) receptor type p55 and p75 in patients with chronic hepatitis $\mathrm{C}$ virus (HCV) infection. Clin Exp Immunol 1998, 111:269-277.

55. Parasole $R$, Izzo F, Perrone F, Pignata S, Galati MG, Leonardi E, Castiglione F, Orlando R, Castello G, Esposito G, Gallo C, Daniele B: Prognostic value of serum biological markers in patients with hepatocellular carcinoma. Clin Cancer Res 2001, 7:3504-3509.

56. Izzo F, Curley S, Maio P, Leonardi E, Imparato L, Giglio S, Cremona F, Castello G: Correlation of soluble interleukin-2 receptor levels with severity of chronic hepatitis $C$ virus liver injury and development of hepatocellular cancer. Surgery 1996, 120:100-105.

57. Priimägi L, Tefanova $V$, Tallo $T$, Schmidt E: The role of serum Th1 and Th2 cytokines in patients with chronic hepatitis $B$ and hepatitis $C$ virus infection. Acta Medica Lituanica 2005, 12:28-31.

58. Sawayama Y, Hayashi J, Kawakami Y, Furusyo N, Ariyama I, Kishihara Y, Ueno K, Kashiwagi S: Serum soluble interleukin-2 receptor levels before and during interferon treatment in patients with chronic hepatitis $B$ virus infection. Dig Dis Sci 1999, 44:163-169.

59. Kitaoka S, Shiota G, Kawasaki H: Serum levels of interleukin-10, interleukin-12 and soluble interleukin-2 receptor in chronic liver disease type C. Hepatogastroenterology 2003, 53:1569-1574.

60. Morshed SA, Fukuma H, Kimura Y, Watanabe S, Nishioka M: Interferongamma, interleukin (IL)-2 and IL-2 receptor expressions in hepatitis C virus-infected liver. Gastroenterol Jpn 1993, 28(Suppl 5):59-66.

61. Khabar KS, Al-Zoghaibi F, Al-Ahdal MN, Murayama T, Dhalla M, Mukaida N, Taha M, Al-Sedairy ST, Siddiqui Y, Kessie G, Matsushima K: The alpha chemokine, interleukin 8 , inhibits the antiviral action of interferon alpha. J Exp Med 1997, 186:1077-1085.

62. Ren Y, Poon RT, Tsui HT, Chen WH, Li Z, Lau C, Yu WC, Fan ST: Interleukin8 serum levels in patients with hepatocellular carcinoma: correlations 
with clinicopathological features and prognosis. Clin Cancer Res 2003, 9(16 Pt 1):5996-6001.

63. Akiba J, Yano H, Ogasawara S, Higaki K, Kojiro M: Expression and function of interleukin-8 in human hepatocellular carcinoma. Int J Oncol 2001, 18:257-264.

64. Fan XG, Liu WE, Li CZ, Wang ZC, Luo LX, Tan DM, Hu GL, Zhang Z: Circulating Th1 and Th2 cytokines in patients with hepatitis $C$ virus infection. Mediators Inflamm 1998, 7:295-297.

65. Zekri AR, El-Din HM, Bahnassy AA, El-Shehabi AM, El-Leethy H, Omar A, Khaled HM: TRUGENE sequencing versus INNO-LiPA for sub-genotyping of HCV genotype-4. J Med Virol 2005, 75:412-420.

66. Ishak K, Baptista A, Bianchi L, Callea F, De Groote J, Gudat F, Denk H, Desmet V, Korb G, MacSween RN, et al: Histopathological grading and staging of chronic hepatitis. J Hepatol 1995, 22:696-699.

doi:10.1186/1476-5926-9-1

Cite this article as: Zekri et al:: Serum levels of soluble Fas, soluble tumor necrosis factor-receptor II, interleukin-2 receptor and interleukin8 as early predictors of hepatocellular carcinoma in Egyptian patients with hepatitis C virus genotype-4. Comparative Hepatology 2010 9:1.

Publish with Biomed Central and every scientist can read your work free of charge

"BioMed Central will be the most significant development for disseminating the results of biomedical research in our lifetime. "

Sir Paul Nurse, Cancer Research UK

Your research papers will be:

- available free of charge to the entire biomedical community

- peer reviewed and published immediately upon acceptance

- cited in PubMed and archived on PubMed Central

- yours - you keep the copyright 